\title{
Fatma Aliye Hanım's Contributions to History Writing
}

\author{
Aliye F. Matarac1 ${ }^{1}$ \\ International University of Sarajevo, Sarajevo, $\mathrm{BiH}$
}

\begin{abstract}
Fatma Aliye Hanım (1862-1936) was one of the first writers to focus on the women's issues in her novels in the Ottoman Empire. She also published a large number of articles focusing on women in varying journals, in addition to her active role in women's associations. Her work did not remain limited with Literature but extended to the other fields such as Education, Sociology, History and Philosophy. This article analyzes her contributions to the Ottoman History via her two historical works: Tarih-i Osmaninin Bir Devre-i Mühimmesi: Kosova Zaferi-Ankara Hezimeti (An Important Era of the Ottoman History: Victory in Kosovo-Defeat in Ankara) published in 1912/1913 and Ahmet Cevdet Paşa ve Zamanı (Ahmet Cevdet Pasha and His Time) published in 1914. Her former work analyzes the significance of the Battle of Kosova (1389) and the Battle of Ankara (1402) for the Ottoman History. Her latter work is a biographical account of his father, Ahmet Cevdet Pasha, who was an Ottoman intellectual, bureaucrat, administrator, and last but not least, a historian. This work focuses on the significance of these two works for Turkish Historiography.
\end{abstract}

Keywords: Fatma Aliye Hanım, history writing, Battle of Kosova, Battle of Ankara, Turkish Historiography

\section{Fatma Aliye Hanım's Contributions to History Writing}

Discovery of Fatma Aliye Hanım in the Turkish Republic, who was one of the first authors to focus on women's issues in the Ottoman Empire, took quite a while. Although she died in 1936, she had to wait till 1990s to be acknowledged. In today's Turkey, she is better known through her works transcribed into modern Turkish from Ottoman Turkish and her photo on 50 Turkish Lira. This article analyzes her contributions to Turkish Historiography via her two historical works: Tarih-i Osmaninin Bir Devre-i Mühimmesi: Kosova Zaferi-Ankara Hezimeti (An Important Era of the Ottoman History: Victory in Kosovo-Defeat in Ankara) published in 1912/1913 (Kırpık, 2012) and Ahmet Cevdet Paşa ve Zamanı (Ahmet Cevdet Pasha and His Time) published in 1914 (Fatma Aliye, 1995). Her former work analyzes the significance of the Battle of Kosova (1389) and the Battle of Ankara (1402) for the Ottoman History. Her latter work is a biographical account of his father, Ahmet Cevdet Pasha (b.1822-d.1895), who was an Ottoman intellectual, bureaucrat, administrator, and last but not least, a historian. Before starting with the analyses of Fatma Aliye's historical works, it may be useful to provide their biographical context.

Fatma Aliye Hanım was born in 1862 as the daughter of Ahmet Cevdet Pasha and Adviye Rabia Hanım in Istanbul. Her father Ahmet Cevdet Pasha was appointed as the inspector general in Bosnia and Herzegovina

\footnotetext{
Aliye F. Matarac1, Assistant Professor, Social and Political Sciences Program, Faculty of Arts and Social Sciences, International University of Sarajevo.

${ }^{1}$ It is a huge responsibility for the author of this article to work on Fatma Aliye Hanım, who was one of the first woman novelists and thinkers of the Ottoman Empire, as Aliye Fatma. It was due to her grandmother's love for Fatma Aliye's novels that she insisted that her granddaughter should be named after her. After a period of negotiation, the author's parents and her grandmother commonly agreed on her name as Aliye Fatma and she tries her best to pay her due.
} 
between 1863 and 1864, immediately following her daughter's birth. Fatma Aliye received a good education starting with her childhood; she began with grammar, cosmography, and astronomy and continued with French, mathematics, history, philosophy and literature. She started travelling with her family as of her early ages due to her father's appointments. Her life became more interesting after her father's appointment as the Governor of Syria in 1878. She accompanied the wives of American and British travelers as a translator during their visits to the Ottoman harems (Sakin, 2012).

On the family return to Istanbul, she got married to Mehmet Faik Bey, one of the captain aides of the Sultan. At the beginning, his husband did not even allow her to read. Her husband's attitude and becoming a mother of two daughters Hatice and Ayse caused a break in her education. Eventually her husband's attitude towards her intellectual activities changed after ten years and he allowed her to translate and publish George Ohnet's first novel Volontè (1888). She published it with the title Meram in 1890 with the simple signature, "a woman". Ahmet Mithat Efendi, a prominent novelist of his time, without knowing who "a woman" was, acknowledged the success of the translation. They started to exchange letters (Esen, 2012). A year later, she co-authored Hayal ve Hakikat (Dream and Truth) with Ahmet Mithat Efendi: the first volume was written by Fatma Aliye and the second one was written by Ahmet Mithat (Canbaz, 2010, pp. 26-27).

Muhadarat (Veiled Women/Muslim Women), her first work published under her name in 1892, was followed by Nisvan-ı Íslam (Women of Islam) published the same year. In this work, she talks about the European misperception of Muslim women as "mazlum" (ill-treated) and "mağdur" (victim) based on her experience with previously mentioned women travelers and travelogues in Syria. Nisvan-l Islam (Women of Islam) was translated into English the same year and into Arabic and French two years later in 1894. Her next novel Refet, published in 1896, focuses on the possibility of woman achieving a respectable position in the society through education. Refet was one of the pioneering novels focusing on women in work life. Her next novel Udi (The Lute Player), published in 1898, was also about the life-story of a working woman, this time a music composer. She gave examples from the lives of non-Muslim women and also appeared as a character in her novel for the first time. Her next publication Levayih-i Hayat (Scenes from Life, 1898) consisted of eleven letters. In this work, she focused on marriages conducted based on parents' decisions, love and harmony between husband and wife, marriages made and continuing due to financial concerns and disloyalty of husband in marriage. Meanwhile, she held discussions with one of the prominent religious thinkers of the period Mahmud Esad Efendi about polygamy in the Ottoman society. Their discussions were published under the title Taaddud-i Zevcat Zeyl (Polygamy Supplement, 1899) (Canbaz, 2010, pp. 27-29)

Fatma Aliye also published in the field of Philosophy: Teracim-i Ahval-i Felasife (Biographies of Philosophers, 1900) was about the life of both Ancient Greek and Islamic philosophers and Tedkik-i Ecsam (Research on Objects, 1901) was about the concept of object in different thought schools. She also gave birth to two more children during these years: Nimet and Zübeyde. Enin, her last novel published in 1910, was an unfinished love story. She also published a large number of articles focusing on women's issues in varying journals, in addition to her active role in women's associations. Her work did not remain limited with literature but extended to the other fields such as Education, Sociology, History and Philosophy as well.

Returning to the main focus of this article after Fatma Aliye's brief biographical sketch, which hopefully will help the reader to contextualize her work; it aims to depict her contributions to the writing of the Ottoman History as stated before. In order to achieve this goal, her two historical works; Tarih-i Osmaninin Bir Devre-i Muhimmesi: Kosova Zaferi-Ankara Hezimeti (An Important Era of the Ottoman History: Victory in 
Kosovo-Defeat in Ankara, 1912/1913) and Ahmet Cevdet Pasa ve Zamanı (Ahmet Cevdet Pasha and His Time, 1914) will be analyzed. Her latter work is a biographical account of his father within which starting with his birth, she narrates the early years of his education, life in medresse, the scientific and literary meetings he attended and the political agenda of the Ottoman Empire until 1885. She considered this work as his will as his father had told her before his death to publish whatever he could not. She accomplished her deed with the support of her circle. This work may also be considered as a reflection of her pain due to the arrestments of Ahmet Cevdet and Mithat Pashas and the trials to follow. Due to the lack of public interest to the published part of her work, she never finalized it and also never published another work. Her impulse may be interpreted as the evolution of her pain into resentment (Canbaz, 2010, pp. 30-31).

Returning to Fatma Aliye's first work in the field of History; Tarih-i Osmaninin Bir Devre-i Muhimmesi: Kosova Zaferi-Ankara Hezimeti (An Important Era of the Ottoman History: Victory in Kosovo-Defeat in Ankara), I would like to start my analyses with a certain question: Why did Fatma Aliye Hanım choose to start contributing to the field of History with a work covering the period of the Battle of Kosovo and the Battle of Ankara? Before providing an answer to this question, it may be useful to remember the historical context of both wars. The Battle of Kosovo occurred between Ottoman and a coalition of Serb, Bulgarian, Albanian, Bosnian and Wallachian Orthodox Christian forces on Kosovo Plain on June 15, 1389, according to the Julian calendar in use by the Serbian Orthodox Church and June 28, according to the Eastern Orthodox calendar. Ever since, this date has been designated as a memorial day named as Vidovdan or St. Vitus' Day to commemorate Prince Lazar and the Serbian martyrs who lost their lives during the battle of Kosovo. Whereas, The Battle of Ankara was fought between the forces of the Sultan Yıldırım Bayezid I and Timur, ruler of the Timurid Empire at the field of Çubuk (near Ankara) on 20 July 1402. The battle was a major victory for Timur, and it led to a period of crisis for the Ottoman Empire known as the Ottoman Interregnum.

Despite the passage of more than six centuries, the winner of this epic battle is still a subject of dispute among historians: "[A]ccording to Balkan Orthodox Christian and nationalist (especially Serbian) historiography, the Ottomans decisively defeated the aforementioned grand coalition of Serb, Bulgarian, Albanian, Bosnian and Wallachian Orthodox Christian forces on Kosovo Plain, shattering the last remnants of the defunct Serbian Empire" (Bideleux \& Jeffries, 2007, pp. 71-72). Whereas, according to revisionist historians like John Fine jnr. (1987) and Noel Malcolm (2002): "losses were heavy on both sides" (p. 20). Prince Lazar was captured and executed but nevertheless, at the close of the battle, the remnants of both the Orthodox Christian and the Ottoman forces withdrew.

Ottoman forces withdrew because of two main reasons: First of all, they lacked the numbers and the strength to continue their offensive against the Balkan Christians. Secondly, Miloş Kabiloviç known as Obiliç, who had ostensibly deserted to the Ottoman side, managed to assassinate Ottoman Sultan Murad Hüdavendigâr (the Devotee of God). His eldest son Bayezid, who commanded the Ottoman forces, felt obliged to pull back his remaining troops in order to secure his own succession to the Sultanate (Bideleux \& Jeffries, 2007, p. 72). According to Fine (1987), "Thus, since the Turks also withdrew, one can conclude the battle was a draw" (p. 410). Since the Serb and Bosnian forces had seemingly held off an Ottoman assault, they initially claimed that they had "won", and they were hailed as saviors of Christendom. Whereas the Serbs had lost a large part of their forces in holding the Ottomans to a temporary draw, the Ottomans still had many thousands of fresh troops in reserve and were able to complete their conquest of the Orthodox Serb lands (other than Bosnian-ruled Hum \& parts of Zeta/Montenegro) by 1392. Although the Serbs may not have formally lost the 
Battle of Kosovo in 1389, "they lost the war because they were no longer able to resist the Ottomans effectively" (Fine, 1987, p. 411). Losses within the Serbian aristocracy were so great that Serbia, thereafter, lost its military and economic resources for further warfare. The commemoration of the Ottoman victory regarding the Battle of Kosovo has not turned into a tradition, whereas Serbs, starting with Vidovdan, have been commemorating June 28 every year (Matarac1, forthcoming 2016).

Going back to the question above regarding Fatma Aliye's motivation to begin her contributions to the field of History with Battles of Kosova and Ankara, I consider the publication year of the work (1912-1913) significant for a possible answer. It may be possible to consider her work as a representation of the impact of the trauma created by the Balkan Wars and the following Ottoman losses in the Balkans. When we look at her endeavors during this period, we can see that she was very active in fund-raising for families of martyrs and war veterans through the charity organization named Nisvan-l Osmaniye Imdat Cemiyeti (Ottoman Women's Association for Aid), which she founded. Again during the Balkan Wars, she lectured at the February 8, 1913 dated meeting of the Müdafaa-i Milliye Osmanl Hanımlar Cemiyeti (Ottoman Women's National Defense Association) and meanwhile evaluating the current situation, she encouraged the Ottoman women to give support to the struggle (Canbaz, 2010, pp. 40-41). Taking her activism during the Balkan Wars into consideration, I think it is important to analyze her work within the context of the Balkan Wars.

The main question which she searches the answer for in her work is: "Why did the Ottoman army loose against Tamerlane, when they won against the coalition army at the Battle of Kosovo? In her introduction (mukaddime), the author draws attention to the number of works which can answer this question, the variety of the answers they offer and the presence of contradictory ones. How Sultan Yildırım Bayezit was treated during his captivity—as a slave or a Sultan—and the contradictory profiles attributed to Tamerlane are among the examples she provides. She argues that such disagreements do not stem from the Bayezit-Timur polarity present among the intellectuals of the period but they were incorporated ahistorically to history writing through stories and hence, figments of imagination. In this regard, she points the significance of the witness of documents for history writing. Meanwhile, referring to the fictive historical narratives as a story, she states that scientific history writing can only be possible by using documents of the period as sources.

Although Fatma Aliye underlines of the significance of the witness of documents for history writing in her foreword, the sources and the documents cited in the rest of her text are pretty limited. In this regard, following the historians of her period, she complies with the mainstream trend of history writing and takes into consideration the source and document citation requirement of modern history only partially. She cites The Muqaddimah of İbn-i Haldûn as a good example for struggling with hearsays. ${ }^{2}$ She mentions that İbn-i Haldûn was able to refute the hearsays via reason and logic. In this regard, she points to the significance of reason, in addition to the witness of documents, in order to separate "rivayet" (rumor) and "hakaylk-ı tarihiye" (historical reality), in contemporary terms; "fiction" and "fact" (Fatma Aliye, 1912/1913, pp. 7-8). With this statement, she refers to İbn-i Haldûn not only as the mentor to be followed regarding methodology in history writing, but also

\footnotetext{
2 İbn-i Haldûn (b.1332-d.1406) was one of the most prominent scholars of Arabo-Muslim culture in the fields of History, Sociology and Philosohpy during the period of its decline. What is now called the Muqaddimah originally constituted the first book of İbn-i Haldûn's great History and it was intended to elucidate the fundamental principles of all history, which determine the true historian's reconstruction of the past. The original "introduction" (muqaddimah) to İbn-i Haldûn's great History covers only a few pages and it contains a eulogy of history, as is customary in Muslim historical works, as stated by Rosenthal. This is followed by a discussion, illustrated with historical examples, of errors historians have committed and the reasons for them (Haldûn, 1967; Oğuz, 2014).
} 
as the pioneer historian to use the elements central to modern history writing, being reason and logic. The fact that she took İbn-i Haldûn as her guide regarding her understanding and writing of history once again draws attention to the parallelism between Fatma Aliye Hanım and the historians of the period. Nevertheless, she inherited this parallelism from his father Ahmet Cevdet Pasha.

Fatma Aliye underlines the power of İbn-i Haldûn's work with this small anecdote: "When the translation of The Muqaddimah of Ibn-i Haldûn was presented to Sultan Mahmud II, his highness told: "Shut up!... You do not give straight razor to a child!..." In this context, it was the "Ottoman Nation" who was referred to as the "child" and the straight razor was The Muqaddimah of İbn-i Haldûn (Fatma Aliye, 1912/1913, p. 10). Another point strongly defended by Fatma Aliye Hanım was the objectivity of the historian. Once again, we get to see another impact of his father. Cevdet Pasha, in his History of Cevdet (Tarih-i Cevdet), mentions that he does not support anyone or any side/camp and he only incorporated the events that he was assured of their truth. Fatma Aliye also mentions that in order for a work of history to be strong, durable and to be accepted by historians, it has to be written by "neutral"; unbiased pens. Even if the historian may be talking about his own nation, he has to acknowledge/report the historic reality as it was. A work involving biased statements and information suspicious regarding its truth and transmitted orally loses its characteristics of being a work of history. Fatma Aliye partially applied these thoughts to her work Victory in Kosovo-Defeat in Ankara by trying to analyze the details of the war, its actors and their attitudes and behaviors in her narration of the Defeat in Ankara.

Due to all these contributions, Fatma Aliye deserves to be taken into account as one of the pioneer women intellectuals writing about Ottoman History, in addition to her literary identity. The male hegemony in the field of Ottoman History makes her contributions only more valuable. Her works provide the first examples of penetration of the woman perspective and voice into the male hegemonic writing of the Ottoman History and in this regard, they are promising for future research regarding the contribution of women perspective to history writing. Her work Victory in Kosovo-Defeat in Ankara is also important because of its mention of women who "made" history during this period. She mentioned the names below in her work due to their interest in power, their impact on internal politics and the roles they played in inter-state relations, not to support her fellow women:

(1) Malhun Hatun (also known as Mal/a Hatun [b.?-d.1323]) was the first wife of Osman I (r. ?-1324), the acknowledged founder of the Ottoman imperial dynasty.

(2) Princess Theodora (b. c. 1332-died after 1381) was a Byzantine princess, the daughter of Emperor John VI Kantakouzenos and the fifth wife of the Ottoman Sultan Orhan I (Gazi/r. 1324-1362).

(3) Serbian Princess Milica (b. 1335-d. 1405) was the wife of Serbian Prince Lazar (r. 1373-1389). After the death of her husband at the Battle of Kosovo in 1389, Milica ruled Serbia until 1393 when her son, Stefan Lazarević Hrebeljanović, came of age to take the throne.

(4) Nefise Sultan (b. c. 1363-d. c. 1400) was an Ottoman princess, the daughter of Sultan Murad I. She was married to Prince Alaeddin Ali of Karaman, who was a rival of the rising Ottoman Empire and became the mother of the next Karamanid ruler, Mehmed II of Karaman.

(5) Devletşah Hatun (b. c. 1365-d. c. 1414) was the daughter of Yakub Bey of the Germiyanoğulları principality and the third wife of the Ottoman Sultan Bayezid I.

\section{Last Remarks}

Last but not least, it is worth mentioning that Fatma Aliye Hanım's contributions to the Turkish cultural 
history were diminished by the efforts to place her within either the secular or the conservative camp. The claim for ownership of her works by both camps pushed for analyses available in current literature. These analyses are mainly efforts to decipher the intention of the author rather than the meaning in the text. In this regard, Fatma Aliye's works can be considered as ill-treated within the current literature due to political pressures.

\section{References}

Bideleux, R., \& Jeffries, I. (2007). A History of Eastern Europe: crisis and change. New York: Routledge.

Canbaz, F. (2010). Fatma Aliye: Fatma Aliye'nin eserlerinde kadın sorunu. Istanbul: Timaş Yayınları.

Esen, N. (2012). Yasaklara rağmen kadın yazar olmak: Ahmed Midhat - Fatma Aliye ilişkisi. Toplumsal Tarih, 32-38.

Fatma Aliye. (1995). Ahmet Cevdet Paşa ve zamanı. M. Hasırcı, (Ed.). İstanbul: Bedir Yayınevi.

Fatma Aliye (1912/1913). Tarih-i Osmanînin Bir Devre-i Mühimmesi Kosova Zaferi-Ankara Hezimeti. Dersaadet: Kanaat Matbaasi.

Fine, J., jnr. (1987). The late Medieval Balkans: A critical survey from the late twelfth century to the Ottoman conquest. Ann Arbor: University of Michigan Press.

Haldûn, İbn-i. (1967). The Muqaddimah: An Introduction to History. N. J. Dawood, (Ed.); F. Rosenthal, Trans. Bollingen Series, Princeton, N. J.: Princeton University Press.

Retrieved from http://www.muslimphilosophy.com/ik/Muqaddimah/TransIntro/TheMuqaddimah.htm.

Kızıltan, M., \& Gençtürk, T. (1993) Atatürk Kitaplığı Fatma Aliye Hanım evrakı kataloğu I, İstanbul: İstanbul Büyükşehir Belediyesi Kültür İşleri Daire Başkanlığı.

Kırpık, C. (Ed.). (2012). Tarih-i Osmaninin bir devre-i mühimmesi: Kosova Zaferi-Ankara Hezimeti, Fatma Aliye Hanım. İstanbul: Kesit Yayınları.

Malcolm, N. (2002). Bosnia: A short history. London: Pan Books.

Matarac1, A. F. (forthcoming 2016). Remembering the Battle of Kosovo (1389). In Proceedings of X. European Conference on Social and Behavioral Sciences, International University of Sarajevo, Sarajevo, BiH, May 19-22, 2016. New York: Peter Lang.

Oğuz, M. (2014) Ahmed Cevdet Paşa ve Tarihçiliği, Konya: Kömen Yayınları .

Sakin, O. (Ed.). (2012). Osmanlı'da kadın: cariyelik, çokeşlilik ve moda, Fatma Aliye, İstanbul: Ekim. 